\title{
Effect of Green Coffee Beans Extract Ointments for Wound Healing
}

\section{Efek Ointment Ekstak Kopi Hijau terhadap Penyembuhan Luka}

\author{
Humaryanto ${ }^{1}$, Ave O Rahman ${ }^{2}$ \\ ${ }^{1}$ Bagian Bedah Fakultas Kedokteran dan Ilmu Kesehatan Universitas Jambi Jambi \\ ${ }^{2}$ Bagian Farmakologi Fakultas Kedokteran dan IImu Kesehatan Universitas Jambi Jambi
}

\begin{abstract}
Some interventions, such as coffee powder, are applied on wound to facilitate healing process. Coffee has several properties that can facilitate wound healing. Application of Robusta coffee bean ointment $22.5 \%$ on full thickness wound could increase fibroblast. Povidone iodine $10 \%$ has remained popular as wound antiseptic. This study aimed to evaluate the effect of green coffee bean extract in lower concentration for healing wound in rats. This study used male Sprague Dawley rats, 10 rats in each group. The skin incision was held in right back of rats with a diameter of $1.5 \mathrm{~cm}$ under lidocaine anesthetic subcutaneously. Group I was not given intervention, group II was given liquid povidone iodine 10\%, and group III was given $15 \%$ green coffee bean extract in vaseline base. Interventions were held every day without wound debridement. Wound size was measured at day 0, 7 and 16. Animals were sacrificed at day 7 (proliferative phase) and 16 (remodeling phase). Sections were stained using Haematoxilyn-eosin. Histopathology assessment of wound tissue is on reepithelization and presence of: inflammatory cells, fibroblast, collagen, and vascularization. Green coffee extract could increase wound contraction and accelerated wound healing. Histopathology result on day 7 showed that green coffee extract had high response inflammatory cells and fibroblast. The provision of $15 \%$ green coffee bean extract ointment can accelerate wound healing with higher inflammation response and fibroblast in proliferative phase .
\end{abstract}

Keywords: Green coffee, histology, wound healing, wound repair

\begin{abstract}
ABSTRAK
Beberapa obat diberikan ke luka untuk mempercepat penyembuhan, seperti bubuk kopi. Kopi mempunyai beberapa senyawa yang mempercepat penyembuhan luka. Pemberian ekstrak kopi robusta $22,5 \%$ pada luka dapat meningkatkan jumlah sel inflamasi, fibroblas dan pembuluh darah, namun povidone iodine $10 \%$ masih sering digunakan sebagai antiseptik luka. Penelitian ini bertujuan untuk mengevaluasi efek kopi hijau dengan kadar lebih rendah terhadap luka pada tikus. Penelitian ini telah mendapat ijin dari komisi etik menggunakan tikus jantan galur Sprague-dawney. Insisi luka dilakukan di punggung kanan berdiameter $1,5 \mathrm{~cm}$ dengan anestesi lidokain subkutan. Group I tanpa perlakuan, group II diberikan povidon iodin $10 \%$, dan group III diberikan salep ekstrak kopi hijau 15\%. Perlakuan diberikan satu kali sehari selama 16 hari tanpa debridemen luka. Ukuran luka diukur pada hari ke 0, 7 dan 16 . Sebanyak 5 ekor tikus tiap kelompok diterminasi pada hari ke 7 (fase proliferasi) dan 5 ekor sisanya diterminasi pada hari ke-16 (fase remodeling) untuk diambil jaringan lukanya. Pemeriksaan histopatologi menggunakan pengecatan Haematoxilyn-eosin dan dilakukan penilaian terhadap reepitelisasi, sel inflamasi, fibroblas, kolagen dan vaskularisasi. Data dianalisis dengan uji Kruskall Wallis. Hasil dari penelitian ini adalah pemberian ekstrak kopi hijau meningkatkan kontraksi luka dan mempercepat penyembuhan luka. Histopatologi hari ke 7 menunjukkan jumlah fibroblast dan sel inflamasi paling tinggi pada kelompok ekstrak kopi. Pemberian salep ekstrak kopi hijau 15\% dapat mempercepat penyembuhan luka dengan peningkatkan sel inflamasi dan fibroblast pada fase proliferasi.
\end{abstract}

Kata Kunci: Histologi, kopi hijau, penyembuhan luka

Korespondensi: Humaryanto. Bagian Bedah Fakultas Kedokteran dan Ilmu Kesehatan Universitas Jambi, Jl. Letjen Soeprapto no. 33 Telanaipura, Kota Jambi (samping RSUD Raden Mattaher Jambi)Tel. (0741)60246Email:fk@unja.ac.id

DOI: http://dx.doi.org/10.21776/ub.jkb.2019.030.03.1 


\section{INTRODUCTION}

Roasting coffee beans powder has been used as traditional medicine in wounds healing. Many local health provides reported coffee powder sprinkled on wound does not cause infection (1). Experimental study with rats has showed result that roasted coffee beans extract ointment base dose $22,5 \%$ could increase inflammatory cells, fibroblast, and blood vessels in wound area on day 4 (2). The chemical constituent of coffee include phenolic compounds and their derivatives (such as chlorogenic acids), alkaloid (especially caffeine), diterpenoid alcohols (such as cafestol and kahweol) (3). Chlorogenic acids has been shown to accelerate the skin wound healing and burn healing $(1,3)$. There are a different chlorogenic acids amount in green coffee and roasted coffee, green coffee has higher amount of chlorogenic acids than roasting coffee beans (3).

One of antiseptic that has been widely used is povidone iodine. Povidone iodine has been used in wound for many decades. In aqueous medium, more free iodine is released into solution from the povidone iodine complex. lodine is a substance that has germicidal activity. The use of povidone iodine for cleansing, irrigating and dressing wounds in controversial. Side effects of iodine in prolong use lead to skin irritation and staining (4). Many studies showed that povidone iodine did not effectively promote good wound healing (5).

Cutaneous wound is repaired by three basic mechanism: connective tissue matrix deposition, contraction and epithelization $(6,7)$. When cutaneous tissue bleeded, the platelet release clotting factors, growth factors and cytokines. These give signal for neutrophils and macrophages to enter the wound site (8). This phase is called inflammatory phase. Neutrophils and macrophages responsible for cleaned out the wound from foreign materials, bacteria and damaged tissue (9). Once the wound site is cleaned out, fibroblast migrate to wound area to begin the proliferative phase. Fibroblast produce a new collagen matrix. Fibroblast undergo a phenotypical differentiation into myofibroblast that have contracting forces to bring the wound edges together (10). New blood vessels enter the wound repair area to supply oxygen and nutrients. This process is called angiogenesis or neovascularization (6). The new collagen matrix then becomes cross linked and organized during the final remodeling phase. In the process of collagen remodelling, collagen degradation occurs by collagenase enzymes. Parallel to all of the mentioned events above, the epithelial-coating cells proliferate and migrate from the border of the wound in an attempt to close it. This is called reepithelization. Reepithelization occurs through the action of specific growth factors and cytokines that are produced by macrophages, platelets and keratinocytes. Once the epithelial bridge is complete, enzyme are released to dissolve the attachment at the base of the scab resulting in removal $(6,11)$.

The three phase of wound healing are not mutually excluding, but rather overlap over time. Inflammatory phase start within the fisrt 24 hours. Inflammatory cells can extended in wound for 12 days. Proliferative phase start after wound site is cleaned out and can unfold up to 14 days after the onset of lesion. This phase is continued by remodeling phase that can last for one year or more (6)

This study is to determine the effect of green coffee beans extract in ointmnet base on wound healing with histology evaluation for epithelization, inflammatory cells, fibroblast, collagen and vascularization on proliferative phase (day 7) and remodelling phase (day 16).

\section{METHODS}

\section{Extraction}

This study used robusta green coffee beans that dried in the oven for $40^{\circ} \mathrm{C}$ for 24 hours and than crushed by blender. Extraction used ethanol $70 \%$ as solvent with ratio 1:3. Rotary evaporator was used to dried the extract. We used vaseline as base for made $15 \%$ ointment of green coffee extracts. Fifteen grams of extract diluted by a little ethanol and added Vaseline up to 100 grams in weight.

\section{Wound Model}

This study has been approved by Ethic Committee of Medical and Health Science Faculty of Jambi University. We used rats strain Sprague dawney, male, age 2-3 months, weight 150-200 grams and healthy. In each left back of rats was made incissions with diameter size $1,5 \mathrm{~cm}$ using scalpel and scissor under anesthesia with lidocaine subcutaneously around incision area. We used ten rats for each groups: 5 rats for subgroup day 7 and 5 rats for day 16 observation. In group I as control, there were no applied dressing on the wound. Groups II were applied povidone iodine solution $10 \%$ and groups III were applied with $15 \%$ ointment of green coffee extracts on the wound. Treatment were held every day without wound debridement.

\section{Wound Contraction and Wound Healing}

Wound area were measured on day 7 and day 16 by tracing the wound area using transparant graph paper.

The evaluated wound surface was used to calculate the percentage of wound contraction (12). Wound healing has complete if wound contraction percentage is $100 \%$. Duration of complete wound healing by counting the number of days from day 0 up to day when wound contraction percentage has been $100 \%$.

Percentage wound contraction was determinated by equation $=\frac{\text { wound area on day } 0 \text {-wound area on } \mathrm{N} \text { th day }}{\text { wound area on day } 0} \times 100 \%$

\section{Histopathology Evaluation}

Histopathology evaluation held on day 7 and day 16 . Five rats in each group were sacrificed on day 7 and day 16 after the incissions to histopathological assesment using haematoxylin eosin (HE) staining. Histological assessment used semi-quantitative methods. They were read by one Anatomical Pathologist with blind method. Scoring for epithelization: $0=$ thickness of cut edges, $1=$ migration of cells $<50 \%, 2=$ migration of cells $\geq 50 \%, 3=$ bridging the excision, 4=keratinization. Scoring for inflammation cells, fibroblast, vascularization and collagen: $0=$ absent, $1=$ mild ST, 2=mild DL/GT, 3=moderate DL/GT, 4=marked DL/GT. (ST=surrounding Tissue, DL=Demarcation Line, GT= Granulation Tissue) $(13,14)$

\section{Statistical Analysis}

Statistical analysis for each parameter mean values \pm SEM of score histopathology, wound contraction and percentage duration of complete wound healing were represented in table and compared using non-parametric 
Kruskall-Wallis Test followed by Mann Whitney test. The level of significance was set at $p<0,05$.

\section{RESULTS}

\section{Wound Contraction and Complete Wound Healing}

The wound healing effect of $15 \%$ ointment of green coffee extracts in wound contraction and complete healing is shown in Table 1 and Figure 1. Wound contraction in group of green coffee extract were highest among the others, followed by no treatment group and povidone iodine group. There was significant difference on wound contraction among the groups $(p=0,003)$. Based on Mann Whitney Test, that significant difference was between green coffee extract group and povidone iodine group $(p=0,001)$.

Table 1. Evaluation of complete wound healing and wound contraction among the groups

\begin{tabular}{lrr}
\hline Groups & $\begin{array}{c}\text { Wound contraction } \\
\text { percentage on } \\
\text { day 7 }\end{array}$ & $\begin{array}{c}\text { Number and percentage of } \\
\text { complete wound healing in } \\
\text { 16 days observation }\end{array}$ \\
\hline Green coffee extract & $82,75 \pm 6,37$ & 5 rats $(100 \%)$ \\
Povidone iodine & $64,60 \pm 10,35$ & 3 rats $(60 \%)$ \\
No treatment & $74,09 \pm 12,56$ & 4 rats $(80 \%)$ \\
P value & 0,003 & 0,311 \\
\hline
\end{tabular}

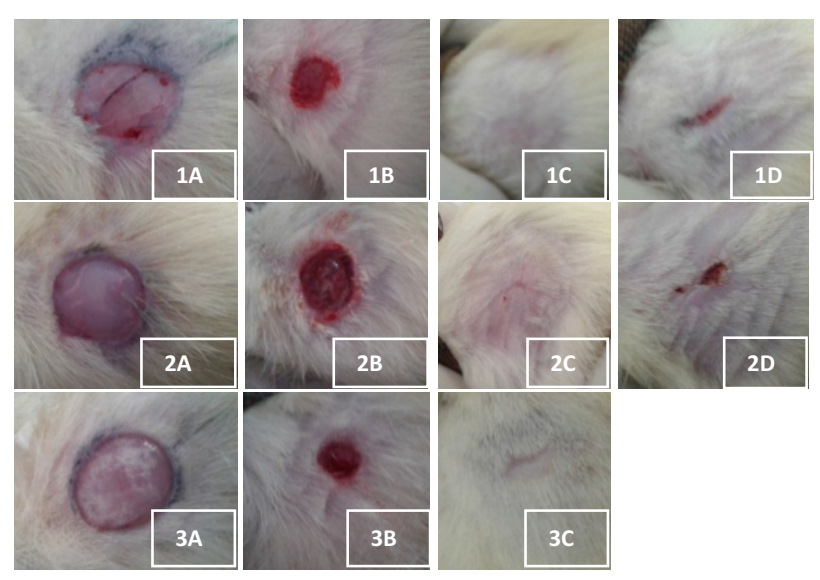

Figure 1. Size of cutaneous wound among the groups

Note: Wound size of no treatment group (1), povidone iodine group (2), green coffee extract group (3). Wound size on day $0(A)$, wound size on day 7 (B), complete wound healing on day 16 (C) and uncomplete wound healing on day 16 (D). Wound size on day 7 in green coffee extract group were seen more narrow than the others

Percentage of complete wound healing in group of green coffee extract were highest among the others. All of rats in this groups had complete wound healing (100\%) in 16 days observation. Duration complete wound healing in group of green coffee extract were fastest among the others (mean 13,6 $\pm 1,34$ days). Wound contraction that observed on day 7 were in mutual with duration complete wound healing. Higher wound contraction would facilitate a faster wound healing. There were 2 rats $(40 \%)$ in povidone iodine group that haven't had complete wound healing in the end of 16 days observation, while only 1 rats $(20 \%)$ that haven't had complete wound healing in no treatment groups.

\section{Histopathology Evaluation}

Histopathology evaluation among the groups on day 7 and day 16 were seen in Table 2 and Figure 2.

Histopathology results of cutaneous wound on days 7 were found that inflammatory cells in green coffee extract group was highest than the others. Also, fibroblast in green coffee extract group was highest among the others. Vascularization in green coffee extract group were lowest among the groups. Collagen level in green coffee extract group were not different with povidone iodine group but it were higher than no treatment group on day 7, there had no epithelization yet in all groups. Myofibroblast, a type of fibroblast, were responsible for wound contraction. Green coffee extract group have highest wound contraction (Table 1 and Figure 1) and highest fibroblast (Table 2) among the others.

Histopathology results of cutaneous wound on days 16 were found that epithelization in green coffee extract group were highest among other groups (Table 2 ). This result was consistent with the result about duration wound healing (Table 1). Inflammatory cell, fibroblast and vascularization were reduce in all groups when compared with day 7, but collagen were increase in all groups when comparing with day 7 . No treatment group had highest collagen among the others.

\section{DISCUSSION}

There are four responses to tissue injury: regeneration, normal repair, deficient, and excessive healing. Regeneration is a process to replace injured structure by replacing exactly what was there before the injury. Normal repair is a response where there is are established equilibrium between scar formation and scar remodeling. This is the typical response that most human experiences following injury. Basically, all cutaneous wound heal by three basic mechanism, they are deposition of connective tissue matrix, contraction and epithelization (15).

Days 7 was selected in this study to represent proliferative phase of wound healing. Based on histopathology results $\mathrm{n}$ day 7 , applying of green coffee extract on skin wound caused higher inflammatory cells and fibroblast level. Inflammatory cells were associated with wound healing for clean the wound area and for stimulating fibroblast migration.

Migration of inflammatory cells to wound area is a crucial steps on wound healing. Inflammatory cells such as neutrophils, monocytes, macrophages release chemoattractant that directing fibroblast to the site of injury $(8,9,16,17)$. Fibroblast undergo a phenotypical differentiation into myofibroblast under stimulus of Transforming Growth Factor $\beta$ (TGF- $\beta$ ) that released by macrophages $(10,16,18)$. TGF- $\beta 1$ and TGF- $\beta 2$ stimulate fibroblast to attach fibrous protein in extracellular matrix via integrin containing adhesions receptor $(15,19,20)$. This binding cause fibroblast to express stress fibers or actin filaments in the cytoplasm. The stress fibers and actin filament are critical to further fibroblast migration and wound contracting forces $(10,18)$.

Migration of fibroblast to wound area need help from fibronectin, tenascin C and proteoglycan $(7,10)$. Then, fibroblast begin to proliferate and produce MMPs (matrix metalloproteinases) and other proteinase to remove 
Table 2. Mean of histopathology scoring on day 7 and day 16

\begin{tabular}{|c|c|c|c|c|c|c|c|c|}
\hline \multirow{2}{*}{ Variable } & \multicolumn{3}{|c|}{ Mean score of day 7} & \multirow[t]{2}{*}{ p value } & \multicolumn{3}{|c|}{ Mean score of day 16} & \multirow{2}{*}{ p value } \\
\hline & KI & KII & KIII & & KI & KII & KIII & \\
\hline Epithelization & 0 & 0 & 0 & 1,000 & $2,4 \pm 2,1$ & $1,6 \pm 2,1$ & 4,00 & 0,141 \\
\hline Inflammatory cells & $3,00 \pm 1,73$ & $3,60 \pm 0,89$ & $3,80 \pm 0,44$ & 0,681 & 2,00 & $2,80 \pm 1,09$ & $2,2 \pm 0,44$ & 0,265 \\
\hline Fibroblast & $3,6 \pm 0,89$ & $3,6 \pm 0,89$ & $3,8 \pm 0,44$ & 0,985 & 2,00 & $2,6 \pm 0,89$ & $2,4 \pm 0,54$ & 0,282 \\
\hline Collagen & $2,6 \pm 0,89$ & 3,00 & 3,00 & 0,287 & 4,00 & $3,6 \pm 0,54$ & $3,6 \pm 0,54$ & 0,280 \\
\hline Vascularization & $3,60 \pm 0,89$ & $3,60 \pm 0,89$ & $3,40 \pm 0,89$ & 0,819 & $2,00 \pm 0,89$ & $2,60 \pm 0,89$ & $2,0 \pm 0,89$ & 0,117 \\
\hline
\end{tabular}
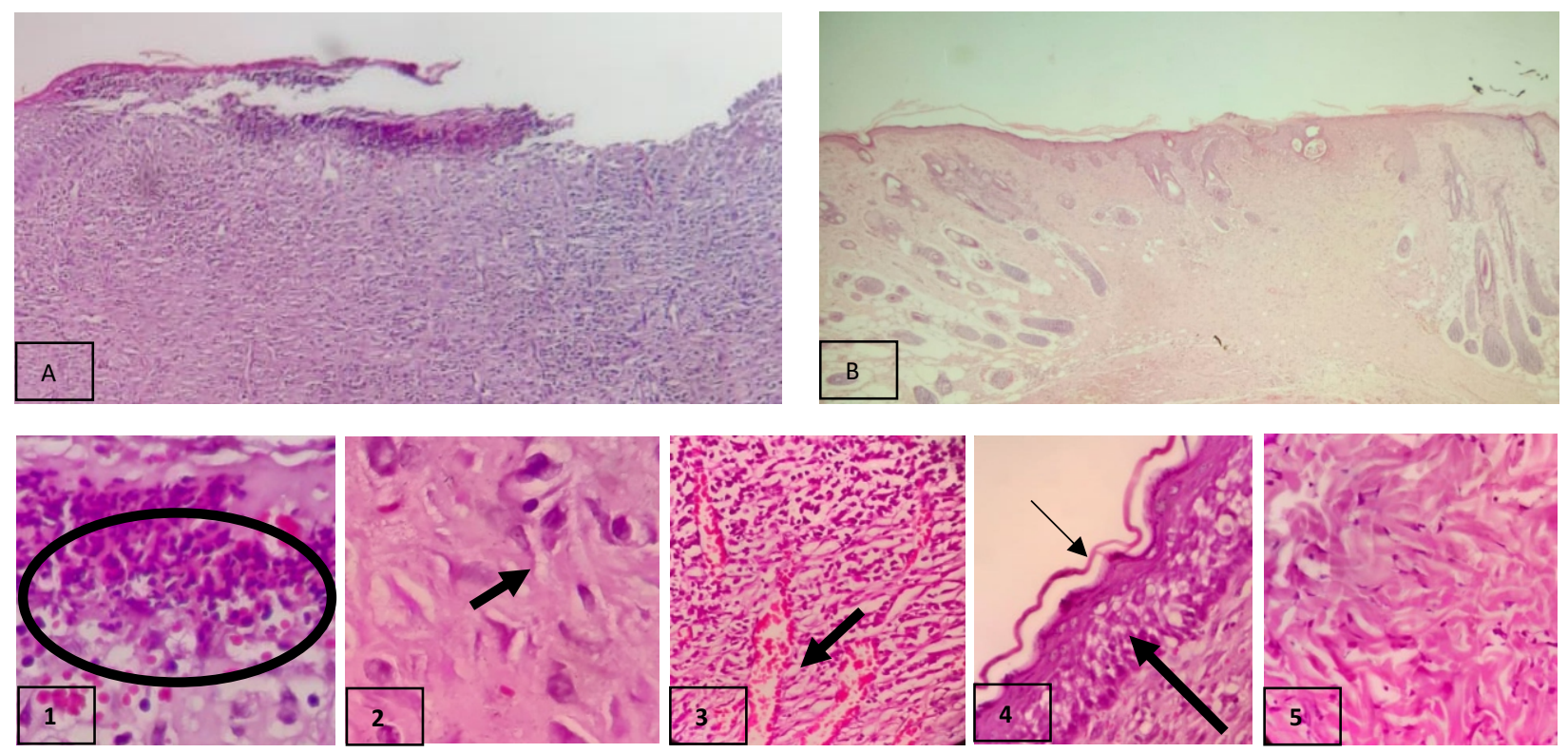

Figure 2. Histopathology of cutaneus wound on green coffee extract group

Note: Histopathology of cutaneus wound healing on day 7 , there had no epithelization yet and had a lot of inflammatory cell (A, magnification 10x). With magnification $40 x$, there seen inflammatory cell $(1$, circle), fibroblast $(2$, arrow), vascularization $(3$, arrow). Histopathology of skin wound healing on day 16 there had complete ephitelization (B, magnification 10x). With magnification 40x, there seen epitel (4, arrow bold) and keratin (4, slight arrow), collagen fiber (5)

denatured protein and provisional matrix-associated material not required in the healed wound $(17,18,24)$. Simultaneously, fibroblast also produce collagen by TGF $\beta$ stimulation. Collagen fibril were further organized into fibrous structure, which it is the framework for epithelialization. Once an abundant collagen matrix has been deposited in the wound, the fibroblast stop producing collagen $(10,15)$. Reepithelization of a wound by keratinocytes is performed by the combination of the proliferative phase with the migration of cells near the lesion by growth factor stimulation. Vascularization has important function to supply oxygen and nutrients $(7,17,21)$.

Day 16 was selected in this study to represent remodeling phase. Remodeling phase exhibits a progressive increase in its collagen fibers level. Finally, collagen remodeling occurs. Specific collagenase enzymes clip the molecules at a specifics site through all three chains and break it down to characteristics three-quarter and one-quarter pieces. These collagen fragments undergo further denaturation and digestion by other protease (6). Remodeling phase is marked by the majority of blood vessel vascularization, fibroblast and inflammatory cells reduced due to emigration processes, apoptosis or other unknown mechanisms of cell death. Fibroblast level decrease to normal level by around day 14 . Fibroblast level decrease to normal level when the new wound extracellular matrix has a similar tensile strength to the surrounding healthy tissue. Fibroblast undergo apoptosis, which could be nitric oxide induced (10).

This study showed that green coffee could help skin wound healing faster than povidone iodine liquids. Wound contraction on day 7 in group that received green coffee extract had highest wound contraction. Wound model in this study is full-thickness wounds that are characterized by complete destruction of the epidermis and dermis as well as deeper structures. Repair of tissue loss is initiated by the formation of granulation tissue that replaces the defect before epithelial covering can occur. Cutaneous wounds close by epithelial resurfacing and wound contraction. Dependent on the species, one or the other process dominates the progress of wound repair. For example, rodents heal mainly by contraction, whereas in humans, reepithelization accounts for up to $80 \%$ of wound closure (7).

The result was supported by histopathology finding on day 7 that fibroblast level in green coffee group was highest among the others. Fibroblast and myofibroblast are responsible for wound contraction, bring the wound edges together. High wound contraction in green coffee group could be associated with duration of wound healing on day 16 , all rats in green coffee group had complete wound closure. Fibroblast level will decrease in remodelling phase, That's why fibroblast were decrease on day 16 in this study compare with day 7. 
As said above, inflammatory cells plays important role in directing fibroblast to the site of injury. In this study, high fibroblast level may be associated with high level of inflammatory cells. Group green coffee extract had highest level of fibroblast and inflammatory cell on day 7.

Active compound in coffee that have wound healing properties is chlorogenic acids $(11,22)$. Aphenolic compound (23). Chlorogenic acids have antioxidative properties to neutralize the effects of oxidative damage to the skin (24), also have antibacterial $(25,26)$, antiviral $(27)$, anti inflammatory $(28,29)$. Chlorogenic acid showed a suppresive activity of metalloproteinase expression (30),

\section{REFERENCES}

1. Yuwono HS. The New Paradigm of Wound Management Using Coffee Powder. Global Journal of Surgery. 2014; 2(2): 25-29.

2. Kenisa YP, Istiati, dan Setyarini WJ. Effect of Robusta Coffee Beans Ointment on Full Thickness Wound Healing. Dental Journal. 2012; 45(1): 52-57.

3. Affonso RCL, Voytena APL, Fanan $\mathrm{S}$, et al. Phytochemical Composition, Antioxidant Activity, and the Effect of the Aqueous Extract of Coffee (Coffea arabica L.) Bean Residual Press Cake on the Skin Wound Healing. Oxidative Medicine and Cellular Longevity. 2016; 2016: 1-10.

4. Dhivya S, Padma VV, and Santhini E. Wound Dressing-A Review. BioMedicine. 2015; 5(4): 24-28.

5. Bigliardi PL, Alsagoff SAL, El-Kafrawi HY, Pyon JK, Wa CTC, and Villa MA. Povidone lodine in Wound Healing: A Review of Current Concepts and Practices. International Journal Surgery. 2017; 44: 260-268.

6. Gonzalez ACO, Costa TF, Andrade ZA, and Medrado ARAP. Wound Healing-A Literature Review. Anais Brasileiros de Dermatologia. 2016; 91(5): 614-620.

7. Sorg H, Tilkorn DJ, Hager S, Hauser J, and Mirastschijski U. Skin Wound Healing: An Update on the Current Kowledge and Concepts. European Surgical Research. 2017; 58(1-2): 81-94.

8. Gray C, Loynes CA, Whyte MKB, Crossman DC, Renshaw SA, and Chico TJA. Simultaneous Intravital Imaging of Macrophage and Neutrophil Behaviour during Inflammation Using a Novel Transgenic Zebrafish. Thrombosis and Haemostasis. 2011; 105(5): 811-819.

9. Rohl J, Zaharia A, Rudolph M, and Murray RZ. The Role of Inflammation in Cutaneous Repair. Wound Practice and Research. 2015; 23(1): 8-15.

10. Bainbridge P. Wound Healing and the Role of Fibroblasts. Journal of Wound Care. 2013; 22(8): 407-412.

11. Bagdas D, Cinkilic N, Ozboluk HY, Ozyigit MO, and Gurun MS. Antihyperalgesic Activity of Chlorogenic Acid in Experimental Neuropathic Pain. Journal of Natural Medicines. 2013; 67(4): 689-704.

12. Ezealisiji $\mathrm{KM}$, Omotosho $\mathrm{AE}$, Udoh $\mathrm{R}$, and Agbo $\mathrm{MO}$. Wound Healing Activity of N-Hexane and Methanol Extracts of Tetracarpidium Conophorum (Mull. Arg) Hutch (African Walnut) in Wistar Rats. Malaysian while others active compound in coffee, caffeine, have peripheral vasoconstrictor effect (31). Polyphenols or phenolic compound also have been showed that could hampering collagen destruction and collagenase activation (30). Extraction methods used in our study extract phenolic compound, but with no quantification of chlorogenic acids in our extract.

In this study, green coffee extract $15 \%$ ointment could accelerate wound healing by increases inflammatory cells and fibroblast in proliferative phase. Further study related to the molecular mechanism of wound healing is needed to investigate coffee and it's active compound that responsible for wound healing.

Journal of Pharmaceutical Sciences. 2014; 12(1): 7988.

13. Gupta A and Kumar P. Assessment of the Histological State of the Healing Wound. Plastic and Aesthetic Research. 2015; 2(5): 239-242.

14. Gal P, Kilik R, Mokry M, et al. Simple Method of Open Skin Wound Healing Model in Corticosteroid-Treated and Diabetic Rats: Standardization of SemiQuantitative and Quantitative Histological Assessments. Veterinarni Medicina. 2008; 53(12): 652-659.

15. Eming SA, Martin P, and Tomic-canic M. Wound Repair and Regeneration: Mechanisms, Signalin, and Translation. Science Translational Medicine. 2014; 6(265): 1-36.

16. Koh TJ and DiPietro LA. Inflammation and Wound Healing: The Role of the Macrophage. Expert Reviews in Molecular Medicine. 2011; 13:1-12.

17. Havran WL and Jameson J. Epidermal T Cells and Wound Healing. The Journal of Immunology. 2010; 184(10): 5423-5428.

18. Darby IA, Laverdet $B$, Bonté $F$, and Desmoulière A. Fibroblasts and Myofibroblasts in Wound Healing. Clinical, Cosmetic, and Investigational Dermatology. 2014; 7: 301-311.

19. Bock O, Yu H, Zitron S, Bayat A, Ferguson MWJ, and Mrowietz U. Studies of Transforming Growth Factors Beta 1-3 and their Receptors I and II in Fibroblast of Keloids and Hypertrophic Scars. Acta DermatoVenereologica. 2005; 85(3): 216-220.

20. Gilbert RWD, Vickaryous MK, and Viloria-Petit AM. Signalling by Transforming Growth Factor Beta Isoforms in Wound Healing and Tissue Regeneration. Journal of Developmental Biology. 2016; 4(21): 1-21.

21. Rittié L. Cellular Mechanisms of Skin Repair in Humans and Other Mammals. Journal Cell Communication and Signaling. 2016; 10(2): 103-120.

22. Bravo J, Arbillaga L, De Peña MP, and Cid C. Antioxidant and Genoprotective Effects of Spent Coffee Extracts in Human Cells. Food and Chemical Toxicology. 2013; 60: 397-403.

23. Brezová V, Šlebodová A, and Staško A. Coffee As $A$ Source Of Antioxidants: An EPR Study. Food Chemistry. 2009; 114(3): 859-868.

24. Ratz-Lyko A, Arct J, Majewski S, and Pytkowska K. Influence of Polyphenols on the Physiological 
Processes in the Skin. Phytotherapy Research. 2015; 29(4): 509-517.

25. Bharath N, Sowmya NK, and Mehta DS. Determination of Antibacterial Activity of Green Coffee Bean Extract on Periodontogenic Bacteria Like Porphyromonas Gingivalis, Prevotella Intermedia, Fusobacterium Nucleatum and Aggregatibacter Actinomycetemcomitans: An In Vitro Study. Contemporary Clinical Dentistry. 2015; 6(2): 166-169.

26. Duangjai A, Suphrom N, Wungrath J, Ontawong A, Nuengchamnong $\mathrm{N}$, and Yosboonruang $\mathrm{A}$. Comparison of Antioxidant, Antimicrobial Activities and Chemical Profiles of Three Coffee (Coffea Arabica L.) Pulp Aqueous Extracts. Integrative Medicine Research. 2016; 5(4): 324-331.

27. Sinisi V, Stevaert A, Berti F, et al. Chlorogenic Compounds from Coffee Beans Exert Activity Against Respiratory Viruses. Planta Medica. 2017; 83(7): 615-
623.

28. Jung S, Kim MH, Park JH, Jeong Y, and Ko KS. Cellular Antioxidant and Anti-Inflammatory Effects of Coffee Extracts with Different Roasting Levels. Journal of Medicinal Food. 2017; 20(6): 626-635.

29. Hwang SJ, Kim YW, Park Y, Lee HJ, and Kim KW. AntiInflammatory Effects of Chlorogenic Acid in Lipopolysaccharide-Stimulated RAW 264.7 Cells. Inflammation Research. 2014; 63(1): 81-90.

30. Chiang HM, Lin TJ, Chiu CY, et al. Coffea Arabica Extract and Its Constituents Prevent Photoaging by Suppressing MMPS Expression and MAP Kinase Pathway. Food and Chemical Toxicology. 2011; 49(1): 309-318.

31. Echeverri D, Montes FR, Cabrera M, Galán A, and Prieto A. Caffeine's Vascular Mechanisms of Action. International Journal of Vascular Medicine. 2010; 2010: 1-10. 